\title{
Identifying 3000-Year Old Human Interaction Spheres in Central Fiji through Lapita Ceramic Sand-Temper Analyses
}

\author{
Roselyn Kumar ${ }^{1, *(1)}$, Patrick D. Nunn ${ }^{2}\left({ }^{-}\right.$and Elia Nakoro ${ }^{3}$ \\ 1 Australian Centre for Pacific Islands Research, University of the Sunshine Coast, \\ Maroochydore, QLD 4558, Australia \\ 2 School of Law and Society/Australian Centre for Pacific, Islands Research, University of the Sunshine Coast, \\ Maroochydore, QLD 4558, Australia; pnunn@usc.edu.au \\ 3 Historical Archaeology Department, Head, Fiji Museum, Government Buildings, Suva P.O. Box 2023, Fiji; \\ rocksfel@yahoo.com.au \\ * Correspondence: rnunn1@usc.edu.au
}

Citation: Kumar, R.; Nunn, P.D.; Nakoro, E. Identifying 3000-Year Old Human Interaction Spheres in Central Fiji through Lapita Ceramic Sand-Temper Analyses. Geosciences 2021, 11, 238. https://doi.org/ $10.3390 /$ geosciences 11060238

Academic Editors: Michael G Petterson and Jesus Martinez-Frias

Received: 13 April 2021

Accepted: 28 May 2021

Published: 31 May 2021

Publisher's Note: MDPI stays neutral with regard to jurisdictional claims in published maps and institutional affiliations.

Copyright: (c) 2021 by the authors. Licensee MDPI, Basel, Switzerland. This article is an open access article distributed under the terms and conditions of the Creative Commons Attribution (CC BY) license (https:/ / creativecommons.org/licenses/by/ $4.0 /)$.

\begin{abstract}
Petrographic analyses of sand tempers in Pacific Island potsherds reveal information about ancient human interactions within archipelagic contexts. By comparison with bedrock mineralogy, analyses of 45 sherds from the Lapita settlement at Naitabale on Moturiki Island (central Fiji) show that most sherds were manufactured locally but that a minority is exotic. Using ternary plots of LFQF-FM (LF-lithic fragments; QF-quartz + feldspar; FM-ferromagnesian), it is shown that exotic material (either pots or temper sands) most likely came from elsewhere in Fiji, probably southeast Viti Levu Island, central Lau, Lomaiviti and Kadavu. Geoscientific analyses of archaeological samples therefore gives us insights into how people likely interacted within the Fiji Archipelago three millennia ago.
\end{abstract}

Keywords: Pacific; Fiji; ceramic mineralogy; sand temper; prehistoric interaction

\section{Introduction}

For most of the three millennia or so that the island groups of the western Pacific Ocean have been occupied by people, they manufactured and used pottery, some of which was decorated in ways that have proved diagnostic of particular places and times [1]. This pottery was also made with locally-sourced sand, used as temper, from the mineralogical analysis of which more precise information about the movements of both pots and potters can be obtained.

The use of sand as temper in ceramics to reconstruct the movements of people and their pots through the Pacific Islands early in their human history was pioneered by geoscientist William R. Dickinson and archaeologist Richard Shutler [2-5], both now deceased. Mainly through petrographic analyses, these authors showed that it was possible to examine the mineral composition of potsherds and determine whether raw materials (volcanic sand) were typical of the geology of rocks in the area where the pottery was recovered (in other words, the pottery was made locally) or whether the sand temper did not derive from the local geology (in other words, the pottery was likely to be imported or exotic). If a particular piece of pottery was exotic, then it was often possible to identify its place (island) of manufacture through its mineral composition. Examples of exotic potsherds identified in this way come from the Marquesas and Tonga [5], Solomon Islands [6] and Tuvalu [7] in the Pacific and among islands in the West Indies [8].

Cross-disciplinary research of this kind at the interface between geoscience and archaeology can improve our understanding of how people, especially in maritime worlds, moved around many thousands of years ago, allowing us to ponder the implications of this. The study presented here explains how the characterization of ancient ceramic sand temper using petrographic analyses, complemented by scanning electron microscopy, was 
used to reconstruct exchange (trade) networks in central Fiji through an analysis of the sand temper of Lapita-era potsherds from the site at Naitabale on Moturiki Island in central Fiji [9].

\section{The Lapita People in the Pacific Islands}

The Pacific Islands east of the main group of Solomon Islands were uninhabited until about 3300 years BP (1350 BCE) when a group of seafaring people, speaking Austronesian languages, began to move from island to island, out from "Near Oceania" to "Remote Oceania" (Figure 1). These peoples are known collectively as the Lapita people. Not only were they accomplished seafarers but they also followed largely marine-subsistence livelihoods, focused on nearshore marine foraging, supplemented by some horticulture. They favoured near-ocean habitation, often in stilt houses above fringing reefs, and made pottery, some of which they decorated intricately and uniquely using a technique known as dentate stamping, which is considered a distinguishing feature of Lapita-era earthenware [10,11].

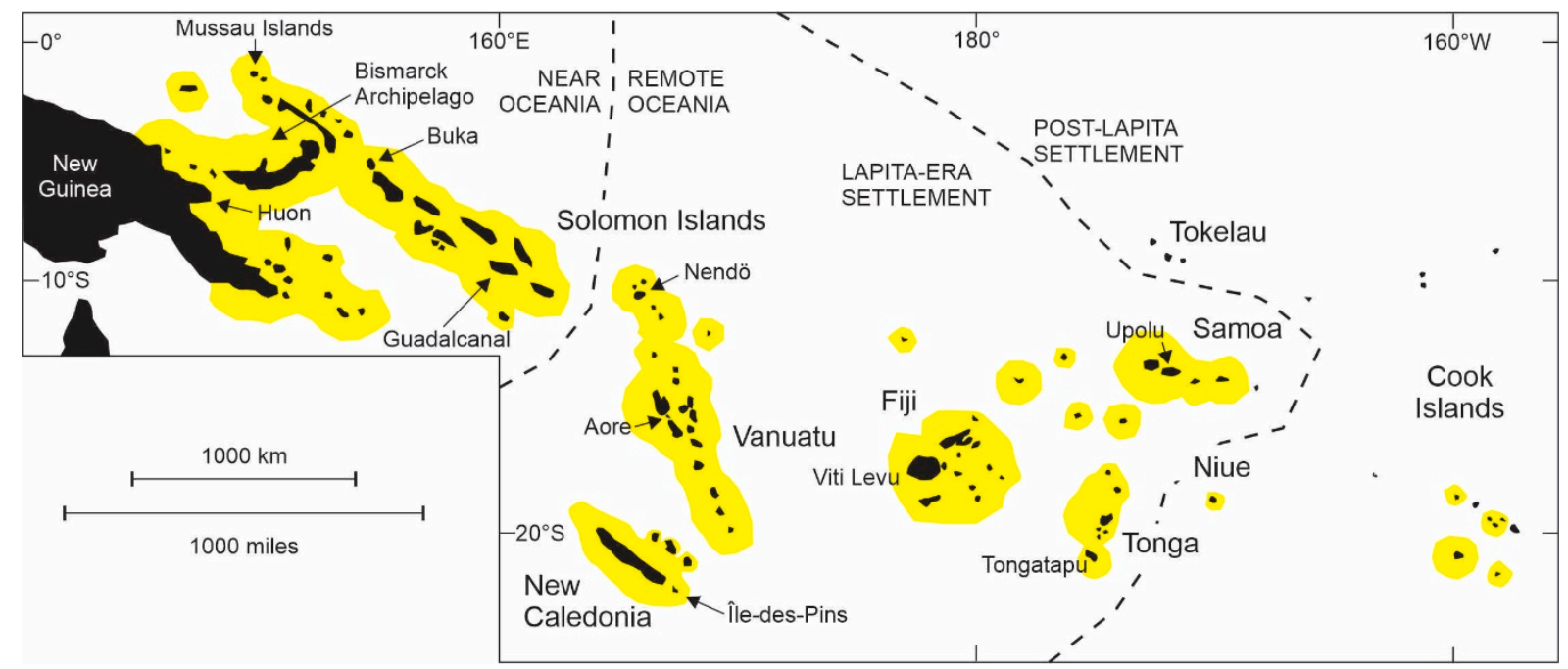

Figure 1. The earliest (Lapita) settlers on islands in the southwest Pacific moved out from the Bismarck Archipelago (Papua New Guinea) about 3300 years ago (cal BP), bypassed the main group of Solomon Islands, to occupy Nendö (eastern outer Solomons), New Caledonia and Vanuatu, before crossing at least $900 \mathrm{~km}$ of open ocean to reach Fiji perhaps 3050 years ago, and reaching Samoa and Tonga before the end of Lapita culture (marked by the end of pottery decoration) about 2500 years ago.

The spread of the Lapita people through the western tropical Pacific was comparatively rapid and must have involved cross-ocean journeys of $900 \mathrm{~km}$ or more. The Lapita people reached the Fiji Islands around 3050 BP (1100 BCE), probably settling first at Bourewa in southwest Viti Levu Island [12-15]. The Lapita era in Fiji, that is the time during which the Lapita people remained recognisable as a distinctive cultural group, is 3050-2500 BP (1100-550 BCE). It is possible that after having established themselves at Bourewa, the Lapita people began moving along the south coast of Viti Levu reaching the islands of central Fiji around 2900 BP (950 BCE) (Figure 2A). Lapita settlements are known to have existed in central Fiji on the islands of Moturiki, Naigani and Ovalau $[9,16,17]$. The site at Naitabale on the south coast of Moturiki Island (Figure 2B) was discovered and excavated in 2002 by a research team from the University of the South Pacific and the Fiji Museum [9] of which the authors were part.

The Naitabale Lapita site was the focus of a study of sand temper that involved the analysis of 45 sherds that were certain (because of their dentate-stamped decoration) to be Lapita in age. Of this total, 15 were analysed by Kumar [18] and 30 were analysed by Dickinson [19]. This paper discusses results of the analysis of Naitabale ceramic sandtemper analyses and explores the implications of these for the reconstruction of ancient interaction spheres. 

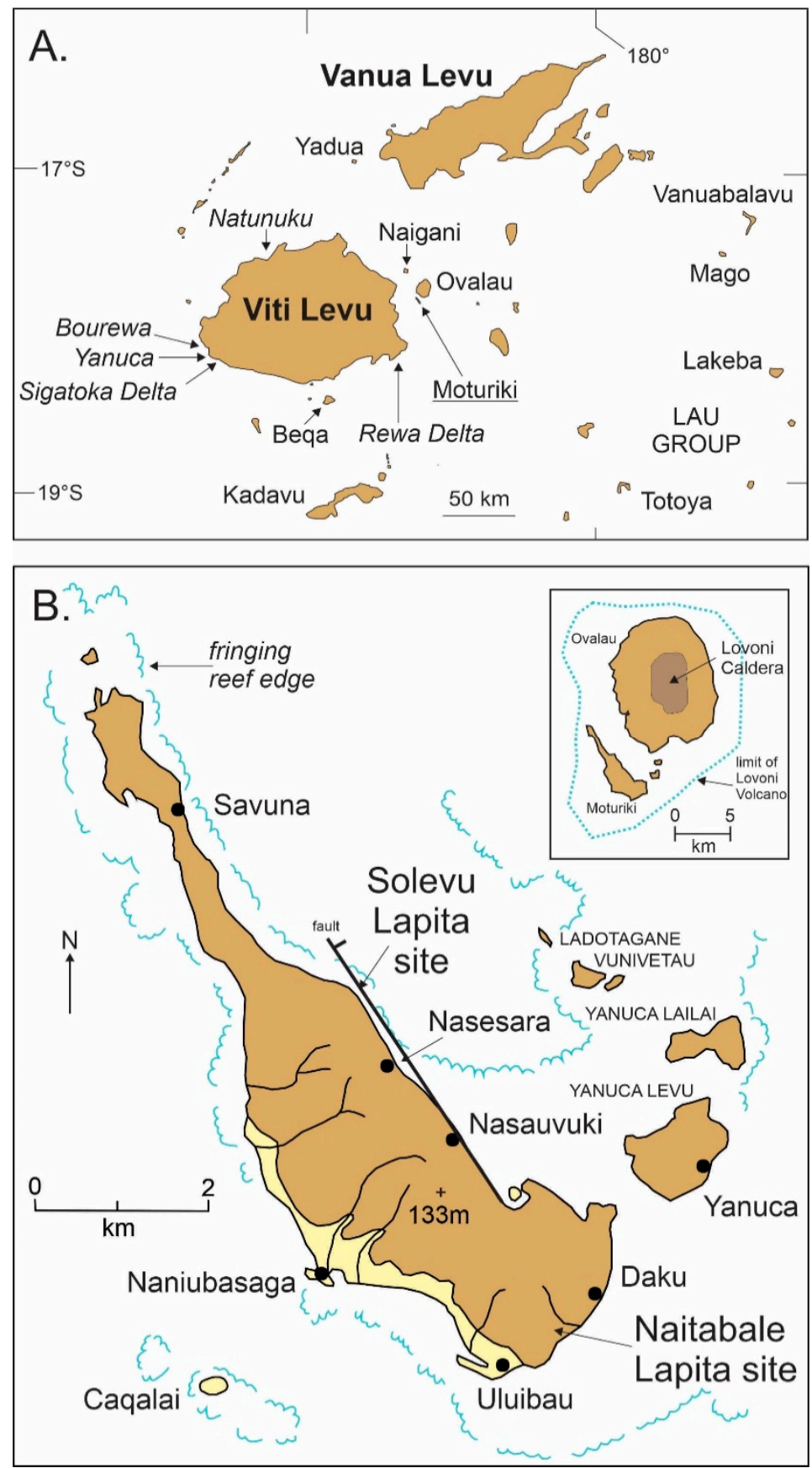

Figure 2. (A) -Map of the Fiji Islands showing the locations of key Lapita-era sites. (B)—Map of Moturiki, showing key features and the location of the Naitabale site where this study is based; inset shows the Lovoni Volcano of which Moturiki Island is part.

\section{The Study Site: Geology and Environment}

Moturiki Island is part of the larger Lovoni Volcano (inset in Figure 2B), dating from the middle Pliocene, which also comprises the adjoining island of Ovalau [20,21]. Moturiki is interpreted as a downfaulted part of the southwest Lovoni Volcano and the range of lithologies it represents is similar to the Volcano and the adjoining islands of which it is also part. Most rocks are andesitic, mostly breccias but with a few exposures of lava. Principal eruptive products are rich in ferromagnesian minerals such as pyroxene, hornblende, opaque iron oxides, and plagioclase feldspars. Quartz and olivine are almost wholly absent and biotite is extremely rare from Moturiki bedrock [18]. 
The Naitabale site on Moturiki Island was established about 3000 years ago $(2950 \mathrm{cal}$ $\mathrm{BP}$ or $1000 \mathrm{BCE}$ ) in the lee of a beach ridge and sand spit, at the mouth of the Mataloaloa River. The shoreline on the other side of the beach adjoined a broad fringing reef, which is thought to have been the main reason for the Lapita people selecting this particular place to live. Their main diet is likely to have been shellfish and other lagoonal and reef-flat foods [22]. The current shoreline is now about 300 metres farther south than it was in Lapita times when the sea level was approximately $1.5 \mathrm{~m}$ higher than it is today [9].

\section{Excavations and Sampling}

Thirteen pits were excavated at the Naitabale site, several reaching almost $2 \mathrm{~m}$ below the surface. Cultural deposits containing Lapita potsherds extended almost all the way through these sediments until the sterile layer (or water table) was reached, suggesting that the Lapita people were the only occupants of this particular site between perhaps $3170 \mathrm{cal} \mathrm{BP}$ (1220 BCE) and $2353 \mathrm{cal} \mathrm{BP} \mathrm{(403} \mathrm{BCE).} \mathrm{Despite} \mathrm{some} \mathrm{disturbance,} \mathrm{most} \mathrm{of}$ the site was intact with sequential radiocarbon ages along the pit profiles [9]. Beneath a surficial disturbed layer there is a layer of brown silt, interpreted as river deposits and postdating the Lapita occupation, below which there is a shell midden. This midden is the key layer to understanding the site's Lapita occupation, containing most of the pottery and other artefacts. Lapita potsherds selected for analysis came from throughout the sequence (but $>50 \mathrm{~cm}$ depth) and represent the duration of the time that Lapita people occupied this site.

Samples were also taken of the bedrock in this part of southern Moturiki Island in order to compare pottery tempers with bedrock mineralogy [18]. The results of the bedrock analyses are not reported in detail in this paper but confirm earlier analyses discussed above of the dominant mineralogies of the Lovoni Volcano.

\section{Analysis, Results and Interpretation}

The sand tempers of the 45 sherds sampled were identified in two main ways. All sherds were thin-sectioned and their mineral assemblages examined under a petrographic microscope; seven of the sherds analysed by Kumar were also examined using the JEOL 733 Electron Microscope at Victoria University Wellington (New Zealand). Figure 3 shows two of the sherds analysed; A is Sherd 56, an example of a standard Moturiki temper; B is Sherd 23, an example of an exotic quartzose temper.

Mineral grains in the pottery thin sections were counted. The results of the mineral counts of the 15 sherds analysed only by Kumar are shown in Table 1 . Note that in each of the count boxes, the percentage figure is followed by (in brackets) the raw count. The analysis shown focuses on the five main groups of minerals counted and this follows the unpublished protocols established by Dickinson $[19,23]$ for Moturiki ceramic sand-temper analyses. The interpretation of temper type (right column in Table 1) utilises these data, particularly as expressed by the pyribole ratio.

$$
\text { (\%clinopyroxene) /(\%clinopyroxene }+\% \text { hornblende) }
$$

which should be about 0.8 for standard tempers from Moturiki. The interpretation of temper type also depends on the presence or absence of exotic minerals like quartz, biotite, olivine, orthopyroxene and others.

The results show that 11 of the 15 sherds (73\%) were almost certainly manufactured using raw materials available on Moturiki Island. Of the remaining four, two (25 and 68) are interpreted as local variants of the standard temper because of their outlier pyribole values while two (sherds 23 and 46) are deemed exotic because they contain quartz. It is likely that these latter two sherds were manufactured somewhere in southeast Viti Levu, where source rocks are rich in quartz and often plutonic in origin. This analysis confirms that not all Naitabale pots were manufactured on Moturiki Island or elsewhere within lands formed by the Lovoni Volcano. 

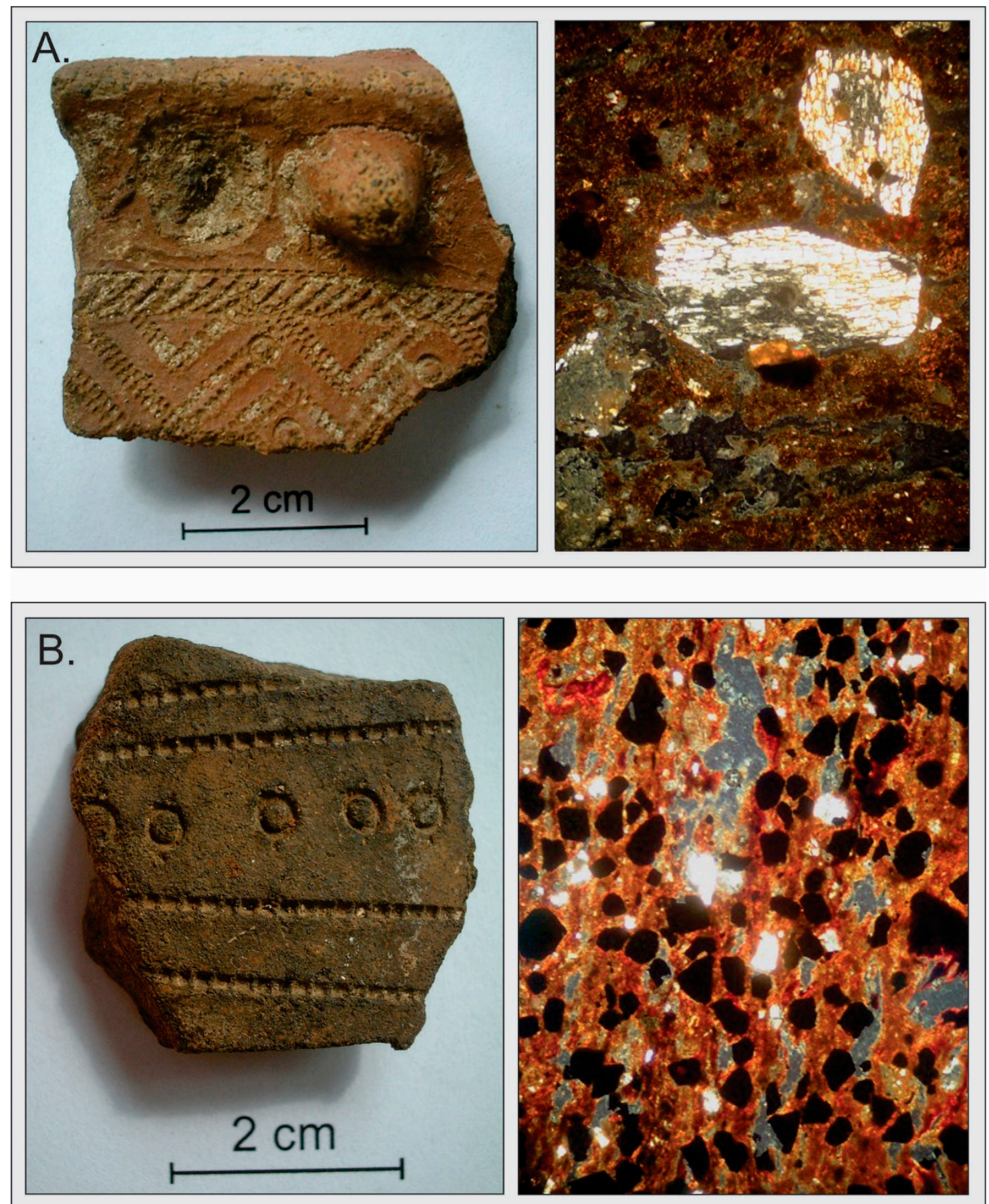

Figure 3. Examples of Lapita (dentate-stamped) potsherds from Naitabale (Moturiki Island) and representative details of their mineralogy (under crossed polarized light). (A)—Sherd 56 (Pit R2, $-65 \mathrm{~cm}$ ) has a standard temper, manufactured locally using volcanic sands dominated by clinopyroxene (63\%), hornblende (12\%) and plagioclase (11\%); magnification $10 \times$. (B)-Sherd 23 (Pit P3, $-145 \mathrm{~cm}$ ) included 23 grains (3\% of total counted) of quartz and is interpreted as exotic (local variant of quartzose temper); magnification $4 \times$. Full details in Kumar [18]. 
Table 1. Mineralogical analyses of sand tempers in 15 Lapita potsherds from Naitabale by Roselyn Kumar reported in this study. Mineral percentages and raw counts (in brackets) are given. Motifs classified according to the system of Anson [24].

\begin{tabular}{|c|c|c|c|c|c|c|c|c|c|c|c|}
\hline $\begin{array}{l}\text { Sherd } \\
\text { Number }\end{array}$ & Pit & Spit (cm) & $\begin{array}{l}\text { Motif } \\
\text { Class }\end{array}$ & $\begin{array}{c}\text { Number of } \\
\text { Grains } \\
\text { Counted }\end{array}$ & $\begin{array}{l}\% \text { Plagio- } \\
\text { clase }\end{array}$ & $\begin{array}{c}\% \\
\text { Clinopy- } \\
\text { roxene }\end{array}$ & $\begin{array}{l}\text { \% Horn- } \\
\text { blende }\end{array}$ & $\begin{array}{c}\text { \% Opaque } \\
\text { Iron } \\
\text { Oxides }\end{array}$ & $\begin{array}{l}\text { \% Volcanic } \\
\text { Lithic } \\
\text { Fragments }\end{array}$ & $\begin{array}{l}\text { Pyribole } \\
\text { Ratio }\end{array}$ & Temper Type \\
\hline 22 & P3 & $140-150$ & M436 & 87 & $8(7)$ & $64(56)$ & $16(14)$ & $7(6)$ & $5(4)$ & 0.80 & standard \\
\hline 23 & P3 & 140-150 & unclassed & 884 & $3(29)$ & $2(14)$ & $1(12)$ & 85 (753) & $3(24)$ & 0.67 & $\begin{array}{l}\text { local variant } \\
\text { of quartzose } \\
\text { temper }\end{array}$ \\
\hline 24 & P3 & $140-150$ & - & 86 & $6(5)$ & $69(59)$ & $16(14)$ & $3(3)$ & $6(5)$ & 0.81 & standard \\
\hline 25 & P3 & 140-150 & M254 & 198 & 19 (37) & $44(87)$ & $16(31)$ & $9(17)$ & $6(11)$ & 0.73 & $\begin{array}{c}\text { local variant } \\
\text { of standard } \\
\text { temper }\end{array}$ \\
\hline 34 & P5 & $130-140$ & unclassed & 125 & $14(18)$ & $30(37)$ & $34(43)$ & $5(6)$ & $17(21)$ & 0.88 & standard \\
\hline 46 & R1 & $100-110$ & M378 & 259 & $53(138)$ & $8(20)$ & $6(16)$ & $6(16)$ & $6(16)$ & 0.57 & quartzose \\
\hline 56 & R2 & $60-70$ & unclassed & 263 & $11(28)$ & $63(167)$ & $12(32)$ & $5(12)$ & $8(20)$ & 0.84 & standard \\
\hline 67 & R3 & 110-120 & M207 & 225 & $8(17)$ & $63(141)$ & $17(38)$ & $12(27)$ & $1(2)$ & 0.79 & standard \\
\hline 68 & $\mathrm{~T} 1$ & $60-70$ & $\begin{array}{l}\text { M207+ } \\
\text { M345? }\end{array}$ & 185 & $23(42)$ & $35(64)$ & $11(20)$ & $14(26)$ & $8(14)$ & 0.76 & $\begin{array}{c}\text { local variant } \\
\text { of standard } \\
\text { temper }\end{array}$ \\
\hline 69 & $\mathrm{~T} 1$ & 120-130 & M175 & 102 & $5(5)$ & $59(60)$ & $25(25)$ & $4(4)$ & $8(8)$ & 0.70 & standard \\
\hline 70 & $\mathrm{~T} 1$ & $120-130$ & M436? & 167 & $5(8)$ & 76 (127) & $16(26)$ & $1(2)$ & $2(4)$ & 0.83 & standard \\
\hline 71 & $\mathrm{~T} 1$ & 130-140 & M154 & 29 & $7(2)$ & $52(15)$ & $28(8)$ & $3(1)$ & $10(3)$ & 0.65 & standard \\
\hline 72 & $\mathrm{~T} 1$ & $130-140$ & M260 & 97 & $4(4)$ & $48(47)$ & $34(33)$ & $10(10)$ & $3(3)$ & 0.59 & standard \\
\hline 73 & $\mathrm{~T} 1$ & $130-140$ & - & 120 & $3(3)$ & $52(62)$ & $35(42)$ & $8(9)$ & $3(4)$ & 0.60 & standard \\
\hline 74 & $\mathrm{~T} 1$ & 140-150 & - & 93 & $2(2)$ & $72(67)$ & $18(17)$ & $5(5)$ & $2(2)$ & 0.80 & standard \\
\hline
\end{tabular}

Note 1. Sherd 23 also included 3\% (23 grains) quartz, 2\% (16 grains) green biotite, 1\% (11 grains) hematite, and $0.2 \%$ ( 2 grains) of altered olivine. Note 2. Sherd 25 also included 3\% (6 grains) biotite and 5\% (9 grains) of orthopyroxene. Note 3. Sherd 46 also contained 10\% (26 grains) quartz, 1\% (3 grains) olivine, 2\% (6 grains) of biotite, 3\% (9 grains) of epidote, and 3\% (9 grains) of hematite. Note 4. Sherd 56 also contained 1\% biotite ( 2 grains) and 1\% altered olivine ( 2 grains). Note 5 . Sherd 68 also contained $6 \%$ (11 grains) of orthopyroxene and $4 \%$ (8 grains) of biotite.

Ternary diagrams were also created to show three main mineralogical ratios appropriate for characterising ceramic sand-temper. These ratios are.

- The LF ratio-lithic fragments; for this purpose, the LF ratio is the percentage of volcanic lithic fragments in Table 1.

- $\quad$ The QF ratio—quartz and feldspar (plagioclase) mineral grains.

- The FM ratio-ferromagnesian silicate and oxide mineral grains (sum of percentages of clinopyroxene, hornblende and opaque iron oxides).

Figure 4 comprises four ternary diagrams showing the LF-QF-FM values for the 45 Moturiki potsherds analysed by both Kumar and Dickinson. Figure 4A is a plot of values for all temper sands from Fiji analysed by Dickinson; five main groups of temper sands are recognised. Figure 4B shows all the Moturiki temper analyses carried out by Kumar. Note that most Moturiki tempers analysed have high FM values compared to others from the Fiji Archipelago. These tempers overlap mostly with the Kedekede, Lomaiviti and Natunuku tempers shown in Figure 4A. The two local-variant tempers (sherds 25 and 68) are close to the standard tempers but with lower FM values and plot within a distinct area, suggesting they are properly classified as "local variant of standard temper" in Table 1.

The two exotic sherds identified are plotted in Figure 4B. The local variant of quartzose temper (sherd 23) has a high iron-oxide value and plots close to the FM corner. The quartzose temper (sherd 46) has a high QF value and plots well away from the rest of the tempers from Moturiki. It is interesting to see that it is close to the Ugaga (Beqa Island) exotic temper (in Figure 4A), which suggests both may derive from a similar quartz-rich source. Both Ugaga and Moturiki are about the same distance (about $25 \mathrm{~km}$ ) from the Rewa Delta, although Ugagan temper sands rich in quartz and feldspar could also have derived from the local Beqa-Yanuca area or from the southeast Viti Levu orogen, transported offshore by the Navua River [25]. 


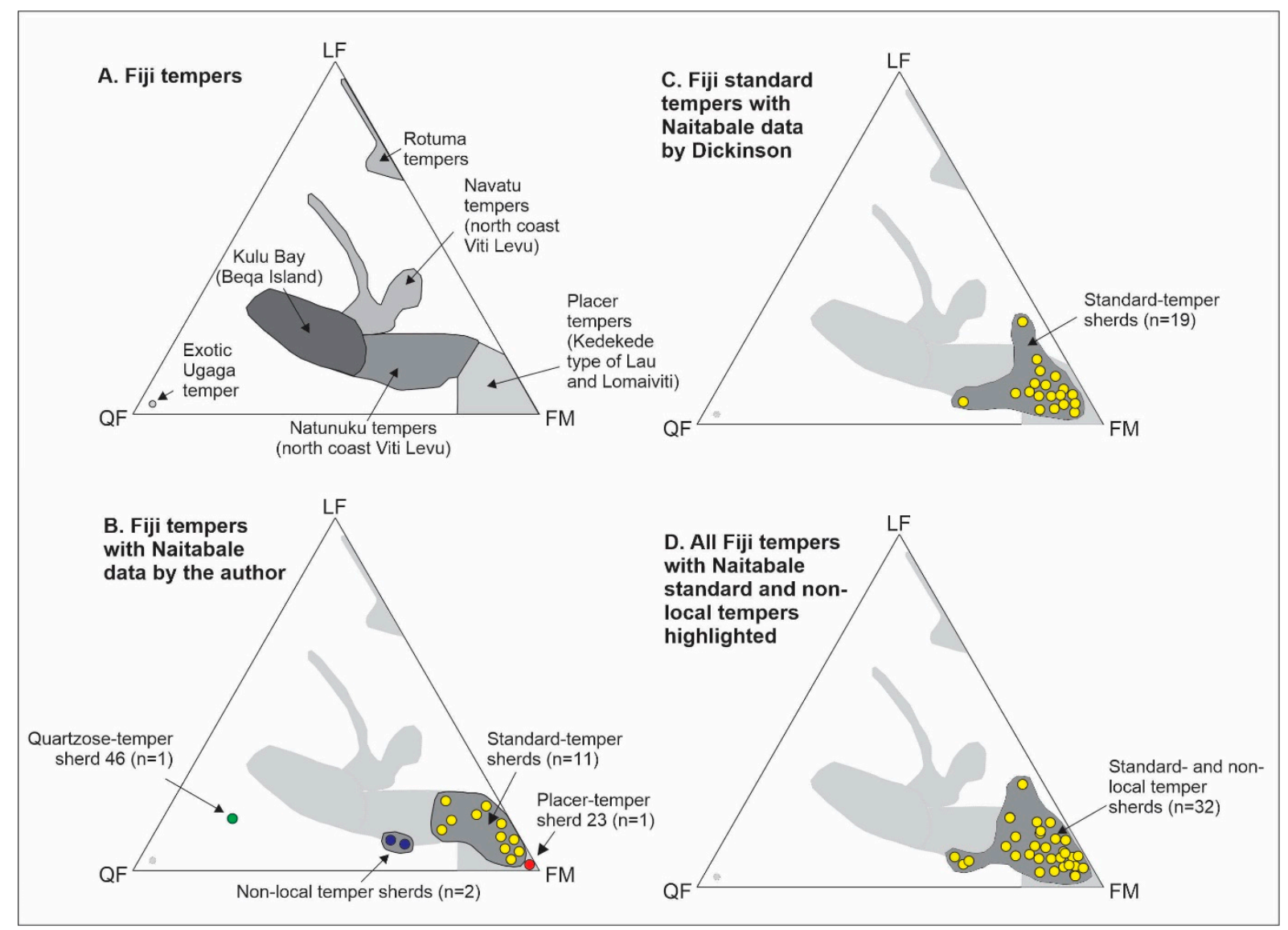

Figure 4. Ternary diagrams showing the LF-QF-FM values for all Fiji sherd tempers. (A)—Characterization of Fiji temper types. (B) —Naitabale sherd tempers analyzed by Kumar. (C)—Naitabale sherd tempers analyzed by Dickinson. (D) — Naitabale tempers.

All the standard tempers of Moturiki sherds analysed by Dickinson are plotted in Figure 4C. They all plot in roughly the same area of the LF-QF-FM triangle as the ones analysed by Kumar (in Figure 4B), evidence of the similarity of the analytical methods used. Figure $4 \mathrm{D}$ is a plot of all the standard tempers (from Figure 4B,C) and shows the similarity in their LF-QF-FM characteristics to the Kedekede (Lau) and Lomaiviti temper types. SEM analysis of seven of the 15 sherds analysed by Kumar confirmed these conclusions.

Some insights into sand-temper provenance can also be gleaned from analyses of sherd decoration through motif analysis $[1,26]$. Of more than 17,000 potsherds recovered from the excavations at Naitabale, just $92(0.5 \%)$ exhibited diagnostic Lapita designs/motifs, the typology of which indicates "a greater affinity with Western Lapita rather than the Eastern Lapita Province where the site is located" ([9], p. 105 therein). This suggests that Naitabale was established early in the 500-year long Lapita history of Fiji ( 3000-2500 BP) when the memory of designs from Western Lapita sites in places like the Bismarck Archipelago and Nendö was still fresh in the potters' minds. Of particular interest is the face-design (anthropomorphic) motif on Sherd 68, also found at the nearby Naigani Lapita site (see Figure 2A), that is considered to have originated in the Bismarck Archipelago and evolved into more abstract forms in New Caledonia and Vanuatu [16]. Around 2500 BP, pottery in Fiji (and elsewhere in the region) ceased to be decorated, marking the end of its Lapita history, a simultaneous event across the western Pacific that can be explained by regional sea-level fall [27].

\section{Discussion: The Lovoni Interaction Sphere in Fiji 3000 Years Ago}

In oceanic and archipelagic contexts before the modern era, connectivities for trade and exchange have commonly been interpreted by archaeologists as 'interaction spheres' [28,29]. 
The shape of particular interaction spheres was clearly determined largely by island geography but it has also been argued as possibly representing kinship networks or strategic alliances [30].

The locally-manufactured potsherds on Moturiki Island (those containing standard tempers) comprise $86 \%$ of those analysed by Kumar and $76 \%$ of those from Naitabale analysed by Dickinson. Two exotic sherds were identified by Kumar-one (sherd 46) quartzose tempered and one (sherd 23) a local variant of a quartzose tempered (see Table 1). Dickinson also identified quartzose-tempered sherds-a total of four of the nine exotictempered sherds. These quartzose-tempered sherds are likely to have come from the Rewa Delta in the southeast of Viti Levu Island, where quartzose-rich sands are brought downstream from the dissected orogen in the island's interior.

The Rewa Delta is only about $25 \mathrm{~km}$ from Moturiki Island, and is renowned today and in historical times for its pottery making [31]. Both clay and sand (non calcareous) are found in large quantities in the Rewa Delta, making it likely to have been a place where pottery manufacture was occurring in Lapita times. No Lapita site has ever been found in the Rewa Delta, but this is not surprising because there has been so much sediment deposition, particularly from inland deforestation, in this area since Lapita times. Yet ceramic sand-temper analyses of Moturiki sherds shows that at least one Lapita settlement must have existed in this area, and that pottery made here was exported to Moturiki Island. It is even possible that the Lapita colonizers of Naitabale on Moturiki Island came originally from a Lapita settlement in the Rewa Delta.

Other exotic-tempered sherds analysed by Dickinson from Naitabale are classified as feldspathic and placer. Dickinson found three feldspathic-tempered sherds among his nine exotic sherds and regarded these feldspathic-tempers as being from the island of Kadavu in the south of Fiji; oxyhornblende and biotite are found in comparatively high proportions in the Kadavu volcanic rocks, and nowhere else in Fiji. He also found two placer-tempered sherds at Moturiki (Kedekede temper type), which he suggested came from Lau Islands to its east.

Most of the Lapita potsherds examined from Moturiki were made locally, on or very close to the Naitabale site; terrigenous sands would have been readily available in the vicinity of the site at the time of its Lapita occupation and are indistinguishable in their mineralogies from those elsewhere in the Lovoni Volcano. Yet there are also some exotic or imported sherds of Lapita pottery found at Naitabale. From the limited sample of 45 sherds, petrographic research found that $11 \%$ are likely to have come from pots manufactured in the Rewa Delta in the southeast part of Viti Levu Island; $11 \%$ were manufactured somewhere on the elongate southern Fiji island of Kadavu; and 7\% were manufactured in the Lau Islands of eastern Fiji, perhaps at the Lapita sites on the islands of Lakeba and/or Mago (Figure 5) [32,33].

This research cannot resolve the question about whether it was the pots that were moved between islands or whether it was the temper sands that were moved. Instinctively it seems more likely that it was the pots that were moved around, some evidently having been carried across great ocean distances elsewhere in the western Pacific, plausibly as prestige goods during the Lapita times [37]. Yet we should not rush to dismiss the idea that temper sands were also moved, perhaps as a contemporary expression of people's attachment to place and the value that was given to material goods/artefacts from sacred/revered places [38].

The most plausible scenario is that during the period that the Naitabale settlement on Moturiki was active, perhaps $3170 \mathrm{cal} \mathrm{BP}$ (1220 BCE) to $2353 \mathrm{cal}$ BP (403 BCE), contact was maintained with contemporary pottery-making settlements in the Rewa Delta, on Kadavu Island, and within the Lau Group. Regular interaction across as much as 200-300 km of open ocean suggests that these were kin networks, similar to those documented in more recent times such as the Kula Ring in Papua New Guinea and the Sawei in Micronesia [39,40]. In support of the kin link is the apparent evidence that other, potentially more easily accessible, Lapita sites (such as those on Beqa, Naigani and Yadua islands-see Figure 5), 
were not part of the Lovoni interaction sphere, given that there is no evidence on Moturiki for the import of pots or temper sands from these places.

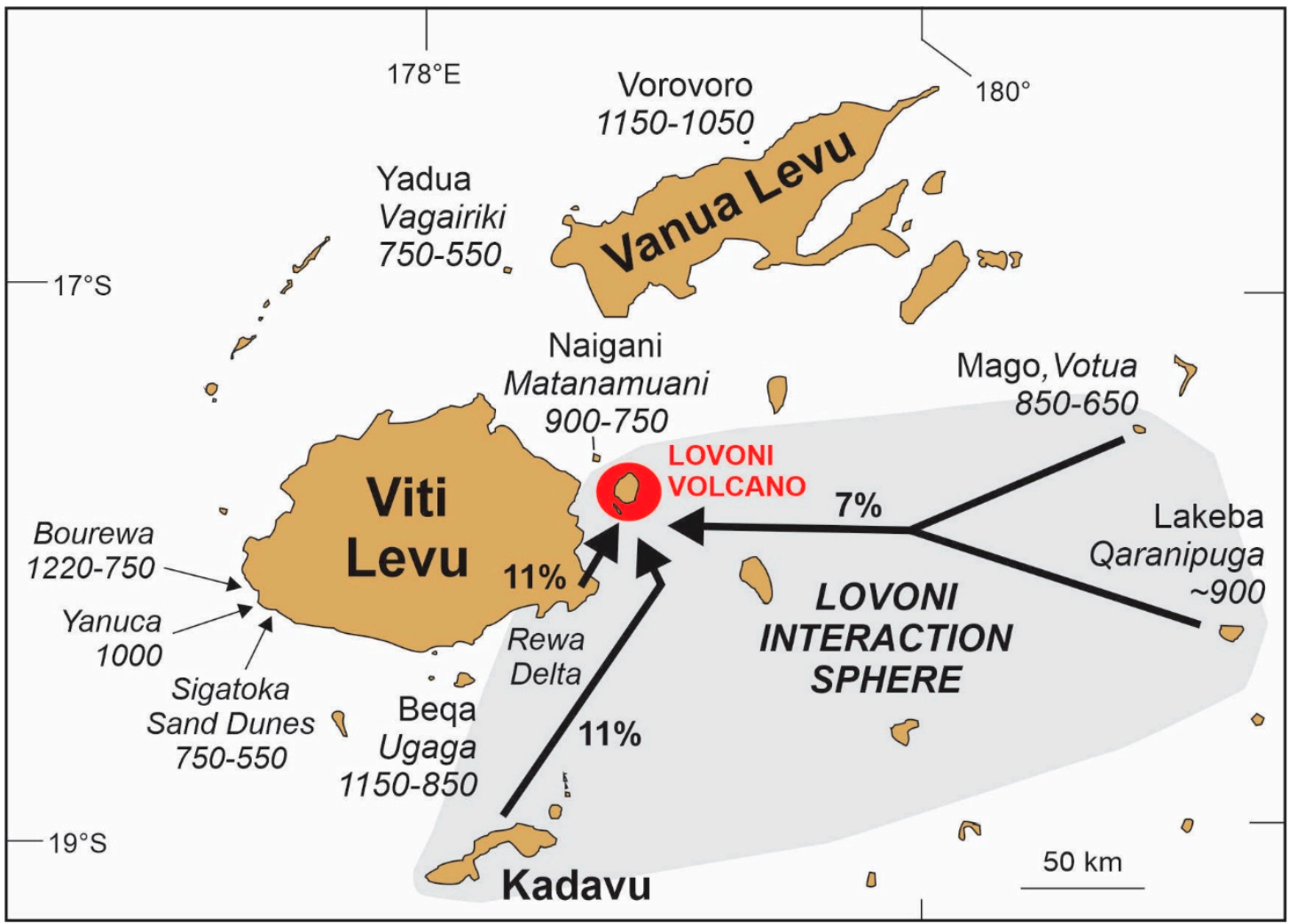

Figure 5. The proposed Lovoni interaction sphere in Fiji which existed during the Lapita-era occupation of Naitabale (Moturiki Island) in the southwest part of the Lovoni Volcano within the period 3170 cal BP (1220 BCE) to 2353 cal BP (403 BCE). Ceramic sand-temper analyses suggests there was regular interaction with Lapita communities (none of which have been certainly identified) in the Rewa Delta (southeast Viti Levu Island) and on Kadavu Island; there was also some moderate interaction with Lapita communities on Lau islands like Lakeba and Mago to the east. Map shows key dated Lapita-era sites elsewhere in Fiji with approximate ages (in years BCE): Bourewa [13,14], Yadua [34], Vorovoro [35], Naigani [16] and others [36].

\section{Conclusions}

The use of optical microscopy and scanning electron microscope analyses in ceramic sand-temper analyses helps to underline the importance of geology to an understanding of ancient peoples and their cultures. This study has shown that the use of temper to reconstruct exchange networks is illuminating and gathering momentum in the Pacific Islands $[3,6,15,41,42]$ and elsewhere in the world $[8,43,44]$.

This type of research provides added insights into pottery manufacture and temper provenance in Fiji three millennia ago and allows the preliminary reconstruction of a trade and exchange network, the Lovoni interaction sphere, within the archipelago. More than this, such research allows the basis for such networks to be pondered-in this case, a kin-based network seems more likely than a pragmatic one (based on proximity) —and also informs the search for undiscovered Lapita-era sites in the Fiji archipelago.

Author Contributions: Concept and design, R.K. and P.D.N.; field survey and sample analyses, R.K., E.N. and P.D.N.; writing R.K., P.D.N. and E.N. All authors have read and agreed to the published version of the manuscript.

Funding: This research did not receive funding.

Data Availability Statement: Not applicable. 
Acknowledgments: This research was carried out by the author under the guidance of the late Professor William R. Dickinson who pioneered the use of temper analyses in the reconstruction of ancient Pacific Island interaction spheres. Before his untimely death, Bill Dickinson authorized the use of his Moturiki temper analyses by the first author. The authors also thank the people of Moturiki Island for their hospitality and support during the fieldwork for this project. Vinaka saka vakalevu nomuni yalovakaturaga, na veiciqomi kei na veitokoni ena nodatou vosota vata na taubi ni uca ena macawa tolu ni noqu vakadidike.

Conflicts of Interest: The authors declare no conflict of interest.

\section{References}

1. LeBlanc, K. A structural approach to ceramic design analysis: A pilot study of the "Eastern Lapita Province". J. Archaeol. Sci. Rep. 2016, 6, 125-135. [CrossRef]

2. Dickinson, W.R. Petrographic temper provinces of prehistoric pottery in Oceania. Rec. Aust. Mus. 1998, 50, 263-276. [CrossRef]

3. Dickinson, W.R. Temper Sands in Prehistoric Oceanian Pottery: Geotectonics, Sedimentology, Petrography, Provenance; Geological Society of America: Boulder, CO, USA, 2006.

4. Dickinson, W.R.; Shutler, R. Implications of petrographic temper analysis for Oceanian prehistory. J. World Prehistory 2000, 14, 203-266. [CrossRef]

5. Dickinson, W.R.; Shutler, R. Probable Fijian origin of quartzose temper sands in prehistoric pottery from Tonga and Marquesas. Science 1974, 185, 454-457. [CrossRef]

6. Buhring, K.L.; Azemard, C.S.; Sheppard, P.J. Geochemical Characterization of Lapita Ceramics from the Western Solomon Islands by Means of Portable X-Ray Fluorescence and Scanning Electron Microscopy. J. Isl. Coast. Archaeol. 2015, 10, 111-132. [CrossRef]

7. Dickinson, W.R.; Takayama, J.; Snow, E.A.; Shutler, R. Sand temper of probable Fijian origin in prehistoric potsherds from Tuvalu. Antiquity 1990, 64, 307-312. [CrossRef]

8. Pavia, J.A.; Marsaglia, K.M.; Fitzpatrick, S.M. Petrography and Provenance of Sand Temper within Ceramic Sherds from Carriacou, Southern Grenadines, West Indies. Geoarchaeol. Int. J. 2013, 28, 450-477. [CrossRef]

9. Nunn, P.D.; Ishimura, T.; Dickinson, W.R.; Katayama, K.; Thomas, F.; Kumar, R.; Matararaba, S.; Davidson, J.; Worthy, T. The Lapita occupation at Naitabale, Moturiki Island, central Fiji. Asian Perspect. 2007, 46, 96-132. [CrossRef]

10. Mead, S.M.; Birks, L.; Birks, H.; Shaw, E. Lapita pottery style of Fiji and its associations. J. Polym. Soc. 1973, 82, 44-98.

11. Kirch, P.V. The Lapita Peoples: Ancestors of the Oceanic World; Blackwell: Oxford, UK, 1997.

12. Nunn, P.D. Echoes from a distance: Progress report on research into the Lapita occupation of the Rove Peninsula, southwest Viti Levu Island, Fiji. In Oceanic Explorations: Lapita and Western Pacific Settlement; Terra Australis 26; Bedford, S., Sand, C., Connaughton, S., Eds.; Australian National University: Canberra, Australia, 2007; pp. 163-176.

13. Nunn, P.D.; Kumar, R.; Matararaba, S.; Ishimura, T.; Seeto, J.; Rayawa, S.; Kuruyawa, S.; Nasila, A.; Oloni, B.; Ram, A.R.; et al. Early Lapita settlement site at Bourewa, southwest Viti Levu Island, Fiji. Archaeol. Ocean. 2004, 39, 139-143. [CrossRef]

14. Nunn, P.D.; Petchey, F. Bayesian re-evaluation of Lapita settlement in Fiji: Radiocarbon analysis of the Lapita occupation at Bourewa and nearby sites on the Rove Peninsula, Viti Levu Island. J. Pac. Archaeol. 2013, 4, 21-34.

15. Dickinson, W.R.; Nunn, P.D. Petrography of sand tempers in Lapita potsherds from the Rove Peninsula, Southwest Viti Levu, Fiji. J. Pac. Archaeol. 2013, 4, 1-17.

16. Irwin, G.; Worthy, T.H.; Best, S.; Hawkins, S.; Carpenter, J.; Matararaba, S. Further investigations at the Naigani Lapita site (VL 21/5), Fiji: Excavation, radiocarbon dating and palaeofaunal extinction. J. Pac. Archaeol. 2011, 2, 66-78.

17. Nunn, P.D.; Matararaba, S.; Areki, F. A Lapita site on Ovalau Island, central Fiji Islands. Archaeol. N. Z. 2004, 47, $215-219$.

18. Kumar, R.R. Petrographic Character and Provenance of Lapita-Era Potsherds from Moturiki Island in Central Fiji: Implications for Early Human Ceramic Exchange; University of the South Pacific: Suva, Fiji, 2007.

19. Dickinson, W.R. Petrography of Sand Tempers in Sherds from Naitabale. Moturiki, Fiji, 2004; Unpublished work.

20. Coulson, F.I.E. Geology of the Lomaiviti and Moala Island Groups; Bulletin 2; Fiji Mineral Resources Division: Suva, Fiji, 1976.

21. Ibbotson, P. The Geology of Ovalau, Moturiki and Naingani; Bulletin 9; Geological Survey of Fiji: Suva, Fiji, 1961.

22. Szabó, K.; Amesbury, J. Molluscs in a world of islands: The use of shellfish as a food resource in the tropical island Asia-Pacific region. Quat. Int. 2011, 239, 8-18. [CrossRef]

23. Dickinson, W.R. Petrography of Sand Temper in a Lapita Sherd from Moturiki. 2001; Unpublished work.

24. Anson, D. Lapita Pottery of the Bismarck Archipelago and Its Affinities; University of Sydney: Sydney, Australia, 1983.

25. Clark, G. Post-Lapita Fiji: Cultural Transformation in the Mid-Sequence; Australian National University: Canberra, Australia, 1999.

26. Terrell, J.; Schechter, E. The meaning and importance of the Lapita face motif. Archaeol. Ocean. 2009, 44, 45-55. [CrossRef]

27. Nunn, P.D.; Carson, M.T. Sea-level fall implicated in profound societal change about 2570 cal yr BP (620 BC) in western Pacific island groups. Geo Geogr. Environ. 2015, 2, 17-32. [CrossRef]

28. Burley, D.V. Fijian polygenesis and the Melanesian/Polynesian divide. Curr. Anthropol. 2013, 54, 436-462. [CrossRef]

29. Cochrane, E.E.; Neff, H. Investigating compositional diversity among Fijian ceramics with laser ablation-inductively coupled plasma-mass spectrometry (LA-ICP-MS): Implications for interaction studies on geologically similar islands. J. Archaeol. Sci. 2006, 33, 378-390. [CrossRef] 
30. Esser, H. The Kula-Ring of Bronislaw Malinowski. A Simulation Model of the Co-Evolution of an Economic and Ceremonial Exchange System. Kolner Zeitschrift Soziologie Sozialpsychologie 2011, 63, 316-320.

31. Rossitto, R. Fijian pottery in a changing world. J. Polym. Soc. 1992, 101, 169-190.

32. Best, S.B. Lakeba: The Prehistory of a Fijian Island; University of Auckland: Auckland, New Zealand, 1984.

33. Clark, G. Ceramic assemblages from excavations on Viti Levu, Beqa-Ugaga and Mago islands. In The Early Prehistory of Fiji; Clark, G., Anderson, A., Eds.; Australian National University: Canberra, Australia, 2009; pp. 259-306.

34. Nunn, P.D.; Matararaba, S.; Ishimura, T.; Kumar, R.; Nakoro, E. Reconstructing the Lapita-era geography of northern Fiji: A newly-discovered Lapita site on Yadua Island and its implications. N. Z. J. Archaeol. 2005, 26, 41-55.

35. Burley, D.V. Exploration as a strategic process in the Lapita settlement of Fiji: The implications of Vorovoro Island. J. Pac. Archaeol. 2012, 3, 22-34.

36. Clark, G.; Anderson, A. (Eds.) Site chronology and a review of radiocarbon dates from Fiji. In The Early Prehistory of Fiji; Australian National University: Canberra, Australia, 2009; pp. 153-182.

37. Summerhayes, G. Lapita Interaction; Australian National University: Canberra, Australia, 2000.

38. Brandenburg, A.M.; Carroll, M.S. Your place or mine-The effect of place creation on environmental values and landscape meanings. Soc. Nat. Resour. 1995, 8, 381-398. [CrossRef]

39. Hunter-Anderson, R.L.; Zan, Y. Demystifying the Sawei, a traditional interisland exchange system. ISLA J. Micrones Stud. 1996, $4,1-45$.

40. Malinowski, B. Argonauts of the Western Pacific: An account of Native Enterprise and Adventure in the Archipelagoes of Melanesian New Guinea; Routledge and Kegan Paul: London, UK, 1922.

41. Dickinson, W.R. Petrography and geologic provenance of sand tempers in prehistoric potsherds from Fiji and Vanuatu, South Pacific. Geoarchaeology 2001, 16, 275-322. [CrossRef]

42. Dickinson, W.R.; Bedford, S.; Spriggs, M. Petrography of Temper Sands in 112 Reconstructed Lapita Pottery Vessels from Teouma (Efate): Archaeological implications and relations to other Vanuatu tempers. J. Pac. Archaeol. 2013, 4, 1-20.

43. Marsaglia, K.M.; Kramer, K.G.; David, B.; Skelly, R.J. Petrographic analyses of sand temper/inclusions in ceramics of Kikiniu, Kikori River and modern sand samples from the Gulf Province (Papua New Guinea). Archaeol. Ocean. 2016, 51, 131-140. [CrossRef]

44. Bebber, M.R.; Spurlock, L.B.; Fisch, M. A performance-based evaluation of chemically similar (carbonate) tempers from Late Prehistoric (AD 1200-1700) Ohio: Implications for human selection and production of ceramic technology. PLoS ONE 2018, 13. [CrossRef] 